\title{
Folkemedisinsk behandling anno 1860
}

Folkemedisinen har vunnet anseelse som ufarlig, uskadelig og god-

hjertet. Vi ser for oss grønne urter og varme hender, magi og guddommelig inngripen. Men i vår folkemedisinske arv finnes en rekke uttrykk for råskap og intoleranse. Jeg viser i denne kronikken eksempler på folkemedisinske råd som ble samlet inn på 1860-tallet. De dokumenterer at uhyggelige gjerninger er utført også av folkemedisinske helbredere.

\section{Erik Ingebrigtsen}

erik.ingebrigtsen@hf.ntnu.no

Institutt for historie og klassiske fag

Norges teknisk-naturvitenskapelige universitet 7491 Trondheim

I bølgen av folkemedisinsk entusiasme knyttet til helbrederen fra Snåsa har både helseminister Bjarne Håkon Hanssen, SVlegen Olav Gunnar Ballo og Helse Norddirektør Lars Vorland bekjent sin åpenhet for fenomener som den moderne vitenskapen ikke kan forklare. I dag må den som ønsker å fremstå som tolerant og liberal omfavne den helbredende kraften som finnes i folkemedisinen, i alternative praksiser og i overnaturlige fenomener. Kritikerne av helsetoppenes bekjennelser fremstår som forstokkede, konservative og sneversynte. Det hører imidlertid med til historien at vi i vår folkemedisinske arv finner en rekke uttrykk for brutalitet og intoleranse. At det $i$ den moderne vitenskapelige medisinens navn har skjedd mye som ikke har vært til pasientens beste, er viden kjent. Dette betyr likevel ikke at alternative praksiser bør være fritatt for kritiske tilnærminger.

En rikholdig kilde til kunnskap om norske folkemedisinske tradisjoner ble samlet inn på 1860-tallet av Johan Theodor Storaker (1837-72). Han var omreisende allmueskolelærer, senere underviste han ved Søgne lærerskole. Gjennom sitt virke samlet han inn dokumentasjon over ulike sider ved folkelige tradisjoner og virkelighetsoppfatninger. Han fikk også sine lærerskoleelever til å nedtegne opplysninger fra hjemstedet. Storaker etterlot seg et omfattende upublisert materiale da han døde bare 35 år gammel. Folkelivsgranskeren Nils Lid (1890-1958) bearbeidet stoffet flere tiår senere, og redigerte hele sju bind av Storakers samlinger i årene 1921-38. I Sykdom og forgjørelse i norsk folketro gjengis oppfatninger fra store deler av landet om ulike lidelser og måten disse kunne behandles på (1). Storakers tilnærming til folkelig kunn- skap har fellestrekk med metoden til Eilert Sundt (1817-75), men siden han ikke rakk å publisere sine data, er hans navn mindre kjent $(2,3)$. Med den forutsetning at rådene som Storaker nedtegnet faktisk ble omsatt i praksis, viser denne samlingen at den folkelige helbredelse verken var «snill» eller «ufarlig». Jeg vil vise utvalgte eksempler på behandling som påførte syke mennesker og samfunnets marginale grupper unødig lidelse, mens andre metoder var direkte skadelige. Men alt er selvsagt ikke bare svart. Gjennom et kurs i blodstemming og et nærmest allmenngyldig trylleformular skal vi se at disse rådene fortsatt kan komme til nytte.

\section{Virksom eller uvirksom?}

Etter mange tiår med en gjennomgående seiersgang for den moderne medisinens prestasjoner og for helsevesenets anseelse kan entusiasmen i retning av det overnaturlige ses som uttrykk for en tillitskrise for den vitenskapelig baserte medisinen. Når helseministeren forteller at sønnens kolikk ble helbredet over telefon (4) og Ballo går Foto Aftenposten/SCANPIX god for at bønner kan stanse blødninger (5), har enkelte kritikere uttrykt bekymring for at syke mennesker vil henvende seg til juksemakere og sjarlataner. Det er skapt en motsetning mellom «ekte» helbredere (Snåsakallen) og «juksehelbredere», der sistnevnte gruppe samvittighetsløst utnytter fortvilte mennesker. Skillet går ikke mellom den vitenskapelig dokumenterte medisinen og kvakksalveriet, men mellom virksomme og uvirksomme behandlere. Hvis vi sammenlikner med debatten bare noen tiår tilbake, viser dette en oppsiktsvekkende mentalitetsendring. Opphevelsen av «kvakksalverloven» i 2003 var et uttrykk for denne trenden, men lovendringen kan også ha bidratt til å sette fart på utviklingen i samme retning.

Snåsakallen fremstår som et godt menneske, og den enorme oppmerksomheten omkring hans person kan ha forsterket oppfatninger om at alternative praksiser er basert på medmenneskelighet. Jeg tror ikke Joralf Gjerstads milde vesen har overføringsverdi til uskolerte helbredere som sådanne, tvert imot gir den gode stemningen rundt alternativ behandling rikelig med spillerom for kynikere. På samme måte er det paradoksalt at den utbredte skepsisen mot den farmasøytiske industrien ikke rammer helsekostprodusenter, som fyller TV-kanalenes reklameflate med kjendiser som går god for deres remedier. Jeg vil imidlertid ikke dvele ved dagens sjarlataner, men returnere til de historiske eksemplene fra Storakers samlinger. De viser at folke-

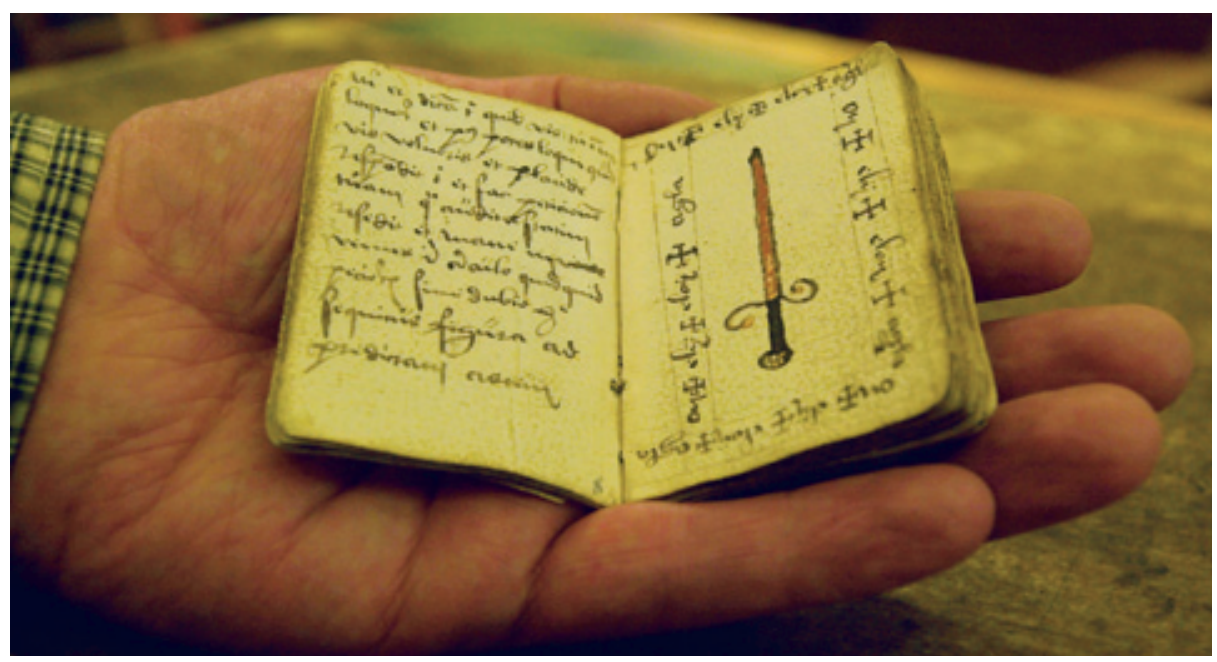

Sator-arepo-formelen er kjent fra det 1. århundre e.Kr. og er blitt brukt mot sykdom helt opp i nyere tid. Den finnes i de fleste europeiske svartebøker. Her Norges eldste svartebok, eid av Oslo Katedralskole. 
medisinen rommet både råskap og bedrag også i det tradisjonelle samfunnet.

\section{Folkemedisinsk behandling Stamming}

På 1800-tallet var det tynt med logopeder, likevel fantes det en rekke råd mot stamming hos barn. Det kan synes som om behandlingsmåtene har vært mer til underholdning for tilskuerne enn til hjelp for det stakkars barnet. Fra Saltdalen finner vi det nokså uskyldige rådet at man skulle slå den stamme over munnen med en levende fisk. I mangel av ferskfisk kunne en våt fille brukes. Selv om det ikke kan ha vært morsomt å bli slått i ansiktet med fisk eller klut, er det ingenting mot situasjonen på Leinstrand sør for Trondheim. Der må det virkelig ha vært uhyggelig å ha denne lidelsen. Rådet derfra lyder: «Naar man har slagtet en $\mathrm{Ku}$, og taget ut Indvoldene, saa kan man tage den Stamme og trykke ham ind i Dyret; Kroppen på dette trækkes sammen, så han holdes vel inde en Stund. Den Stamme maa Intet vide herom i Forveien, men maa tages med Magt og føres ind i Kroppen.» Prøv å se for deg barnet som skjønner at straffen for å fortsette stammingen er å bli tvunget inn i en varm og blodig buk for så å ligge der «en Stund». Barna ble nok kurert - om ikke annet så gjennom å utvikle en vedvarende stumhet!

\section{Dyresykdommer}

På samme måte finner vi hos Storaker en mengde råd som illustrerer utbredte fordommer mot samer, finner og omstreifere. Eksempler fra hele landet viser at dyresykdommer ofte ble forklart med at samer, finner (kvener), tatere eller fanter hadde kastet trolldom over dyret. Rådene for å omgjøre trolldommen spenner fra det ettergivende (alltid å gi samer/finner/ omstreifere det de ber om) til det sadistiske. Mange steder mente man at den beste måten å bryte trolldommen på var å slå den som hadde påkalt dyrets sykdom til blods. $\AA$ vite nøyaktig hvem som var den skyldige må ha vært vanskelig, så da var det kanskje best å gå bredt ut? Fra Steigen i Nordland rapporterte Storaker om en spesiell teknikk. Samen skulle holdes i nesen samtidig som han ble påført et kraftig slag i nakken. Når nesen knakk og blodet sprutet, ville trolldommen bli brutt og dyret bli friskt. Forutsatt, selvfølgelig, at det var den riktige samen som ble slått.

\section{Øyesykdommer}

Rådene i Storakers samling er delvis delt inn etter type lidelse, delvis etter sykdomsårsak. Det er slående hvor grunnleggende de folkelige oppfatningene om diagnose og behandling skilte seg fra den vitenskapelige medisinen, som i perioden befant seg i en overgangsfase mellom humoralpatologien og den anatomiske patologi (6). Selv om det av denne grunn er vanskelig å evaluere virkningen av folkemedisinen både opp mot datidens og våre dagers etablerte kunnskap, fremstår en hel del råd som direkte farlige for pasienten. Ta for eksempel punktene angående «Sykdom i Øiet»: Hvis noen hadde fått rusk på øyet i Fron i Gudbrandsdalen, måtte de håpe og be at hjelperen var stø på hånden. Fremmedlegemet ble enklest fjernet «med en Kniv, hvormed Folk er dræbt». Heller ikke på Manger i Hordaland var det noen spøk å bli behandlet for øyelidelser, i tuberkulosens og andre infeksjonssykdommers tid: «Bliver en syg $i$ et Øie, saa læser en Kvinde nogle Ord gjennom en Flaskehals, hvori der er Brystmelk, og saa spytter hun 3 gange; dette brukes da som Medicin.»

\section{Blodstemming}

Mens det altså fantes råd som ga rikelig utløp for å plage og mishandle utsatte grupper og andre som påførte både lidelse og fare for den syke, inneholder samlingen en rekke råd som neppe gjorde stor skade. Et godt eksempel er blodstemming, som har vært i vinden etter at både Ballo og Vorland har gått god for metoden (7). For å unngå at enda flere skal være nødt til å betale blodpris til en helbreder etter uforsiktig omgang med brødkniven, kan jeg med utgangspunkt i Storakers råd tilby et lynkurs. En advarsel er på plass: Hvis man lærer dette bort til noen, forsvinner evnen! Min karriere som blodstemmer er altså med dette over før den har begynt. Denne kjedelige konsekvensen av å spre kunnskapen kan forklare hvorfor det er så langt mellom blodstemmerskolene.

$\AA$ stanse blødninger har forskjellig vanskelighetsgrad, og neseblod fremstår hos Storaker som det enkleste å kurere. Ifølge et råd fra Trondheim kan dette gjøres ved å binde en tråd rundt lillefingeren. Større blødninger krever mer øvelse, og her er det også ulike råd fra forskjellige steder i landet. Et vers fra Nordfjord, som kanskje ble foretrukket av mannlige behandlere, lyder: «Stat (dvs. stopp) blod, ligesom Kjærringer i Helvede stod.» Dette må sies tre ganger. Ett annet, mer bibelskinspirert vers lyder slik: «Som Jordans Flod stod, så stemmer jeg dit Blod.» For å bedre effekten, må både Faderen, Sønnen og Den Hellige Ånd påkalles før verset leses. Den mest elegante måten å stanse blod på er likevel utvilsomt «de fem Satans Linier». Navnet skyldes ikke at dette er svartekunst, men at trolldomskraften er så sterk at ikke engang Satan kunne forklare linjenes magi. Verset lyder:

SATOR

AREPO

TENET

OPERA

ROTAS

Magiens kraft skyldes at når linjene er satt opp rett under hverandre, kan de leses i alle retninger, ovenfra og ned, nedenfra og opp, fra høyre mot venstre og fra venstre mot høyre. Bare prøv. Det blir «sator, arepo, tenet, opera, rotas» uansett. I Storakers samlinger er det ikke foreskrevet noen dose, men man skulle tro at et par lesinger bør holde, selv for en kraftig blødning.

\section{Et godt råd}

Som rådene mot stamming, dyresykdommer og en rekke andre eksempler viser har folkemedisinen ikke alltid vært medmenneskelig og godhjertet. Den har heller ikke vært ufarlig eller fri for bivirkninger. Samtidig er det mange råd som ville vært til stor nytte $i$ vårt moderne samfunn. Rådene ble samlet inn i en tid da verken leger eller andre kunne gjøre noe særlig for å avhjelpe en rekke plager. Mange behandlinger gikk derfor ut på å få folk til å slutte å syte. Det gjengis over 30 råd mot tannpine, som må ha vært en utbredt og plagsom lidelse. Metoden fra Meløy i Nordland er typisk: «En Maade, hvorpaa man kan blive Tandpine kvit, er ikke i 7 Aar at nævne Tandpine.» Dette er genial trolldom - gratis, fri for bivirkninger, en velsignelse for omgivelsene og umiddelbart overførbar til de fleste hverdagslige plager. Tenk bare på ryggsmerter, idrettsskader, forkjølelse, hodepine, magetrøbbel og en rekke andre sykdommer: Hold det for deg selv en sju års tid, så skal du se hvor godt det hjelper. Og som alle influensarammede menn vet: Det er ingen vits å lide hvis det må skje i stillhet. Etter som spedbarn vokser til, skulle man tro at den foreskrevne sjuårsperiode kunne hjelpe foreldre som er søvnløse pga. kolikk. Hvis helseministeren skulle ringe, kan det i alle fall være vel verdt å prøve ut.

Oppgitte interessekonflikter: Ingen

\section{Litteratur}

1. Storaker JT. Sykdom og Forgjørelse i den norske Folketro. I: Lid N, red. Storakers samlinger. Bd. 28 serien Norsk Folkeminnelag. Oslo: Norsk Folkeminnelag, 1932

2. Christiansen RT. Johan Theodor Nielsen Storaker. I: Norsk biografisk leksikon. Bd. 15. Oslo: Aschehoug, 1966.

3. Refsum H Nils Lid I. Norsk biografisk leksikon. Bd. 8. Oslo: Aschehoug, 1938.

4. Ertzaas $P$, Nielsen A. - Snåsamannen kurerte min sønn. VG 26.1.2009. www.vg.no/helse/artikkel. php?artid=546595 (10.2.2009)

5. Johansen M, Ertzaas P. - Blødninger kan stanses med religiøse vers. VG 29.1.2009. www.vg.no/ helse/artikkel. php?artid=536691 (10.2.2009)

6. Carstens S. Lokal sykehusutvikling i en vitenskapelig brytningstid: Trondhjems Borgelige Sygehus, senere Trondhjems Communale Sygehus 1805-1902. Doktoravhandling (dr.art.). Trondheim: Det historisk-filosofiske fakultet, Norges teknisknaturvitenskapelige universitet, 2006: 26-55.

7. Lillebø IA. Åpen lege og toppsjef. Avisa Nordland 3.2.2009. www.an.no/nyheter/article4097122.ece (10.2.2009)

Manuskriptet ble mottatt 9.2. 2009 og godkjent 26.2. 2009. Medisinsk redaktør Erlend Hem. 